\title{
Pengaruh Pemberian Ekstrak Herba Ciplukan (Physalis Angulata L) Terstandar Fisalin Terhadap Perubahan Berat Badan Tikus (Sprague Dawley) Hiperglikemia
}

\author{
Maria Rosa Da lima Eno ${ }^{1}$, Yeny Sulistyowati ${ }^{2}$, Idi Setyobroto ${ }^{3}$ \\ ${ }^{1}$ Universitas Respati Yogyakarta, ${ }^{2}$ Universitas Respati Yogyakarta, ${ }^{3}$ Poltekes Kemenkes \\ Email: yeny.sulistyowati@urindo.ac.id
}

\begin{abstract}
Abstrak
Diabetes Mellitus (DM) telah menjadi ancaman serius bagi masyarakat Indonesia yang diperkirakan melebihi 21,3 juta jiwa pada tahun 2030 mendatang dan membutuhkan biaya perawatan yang sangat mahal. Masyarakat perlu mengetahui gejala-gejala timbulnya kasus DM seperti penurunan berat badan. Dengan adanya pencegahan penurunan berat badan menggunakan ekstrak herbal ciplukan terstandar fisalin dengan variasi dosis yang tepat diharapkan dapat mencegah terjadinya penurunan berat badan. Tujuannya adalah untuk mengetahui pengaruh pemberian ekstrak herba ciplukan terstandar fisalin (Physalin angulata L.) terhadap perubahan berat badan tikus (Sprague dawley) yang di induksi Nicotinamide dan Streptozotocin. Penelitian ini merupakan penelitian eksperimental dengan rancangan pre testpost test design menggunakan kelompok tikus SD kontrol dan perlakuan dengan rancangan sederhana dengan berat badan 180-220 gr dengan pemberian ekstrak herba terstandar fisalin fisalin $20 \mathrm{mg} / \mathrm{kg}$ BB selama 21 hari yang di lakukan uji beda data menggunakan independent TTest. Hasil penelitian menunjukan bahwa pengaruh pemberian ekstrak herba ciplukan terstandar fisalin terhadap perubahan berat badan berdasarkan hasil uji statistik Independen TTest yang mendapatkan nilai yang tidak signifikan $p=0,47$ dan asupan makan pada tikus hasil uji Independent T-Test menunjukkan hasil yang signifikan yaitu $p=0,002$. Pemberian ekstrak herba ciplukan terstandar fisalin terhadap perubahan dengan dosis $20 \mathrm{mg} / \mathrm{kg}$ BB belum efektif untuk meningkatkan perubahan berat badan pada tikus DM.
\end{abstract}

Kata Kunci : Diabetes Mellitus, herba ciplukan, perubahan berat badan.

\begin{abstract}
Diabetes Mellitus (DM) has become a serious threat for Indonesian population. It is estimated the quantity will be over 21.3 millions in 2030 and the treatment will be very costly. The community needs to know symptoms of DM cases such as weight loss. Physalin standard ground cherry extract supplementation in varied appropriate dosage is expected to prevent weight loss. Objective the study was identify effect of physalin standard ground cherry extract supplementation (Physalis angulata L.) to weight change of mice (Sprague dawley) induced with Nicotinamide and Streptozotocin. The study was an experiment with pre test-post test design. It used Sprague dawley mice as control and experiment with simple design of weight 180-220gr given physalin standard ground cherry herbal extract of $20 \mathrm{mg} / \mathrm{kg}$ weight within 21 days. Data analysis used independent t-Test. The result of the study was effect of physalin standard ground cherry herbal extract supplementation to weight change based on the result of independent t-test was insignificant whereby $p=0.47$ and food intake of the mice based on the result of independent t-test showed significant result with $p=0.002$. Physalin standard
\end{abstract}

http://ejournal.urindo.ac.id/index.php/pertanian

Article History :

Sumbitted 29 Desember 2020, Accepted 30 Desember 2020, Published 31 Desember 2020 
ground cherry herbal extract supplementation with dosage of $20 \mathrm{mg} / \mathrm{kg}$ weight was ineffective in increasing weight of DM mice.

Keywords: diabetes mellitus, ground cherry, Physalis angulata L, weight change

\section{PENDAHULUAN}

American Diabetes Association (ADA) menyatakan bahwa Diabetes Mellitus (DM) merupakan suatu kelompok penyakit metabolik dengan karakteristik hiperglikemia yang terjadi karena kelainan sekresi insulin, kerja insulin atau keduaduanya. Sedangkan menurut World Health Organization (WHO) 1980 menyatakan bahwa Diabetes mellitus merupakan suatu kumpulan problem anatomik dan kimiawi yang merupakan akibat dari sejumlah di mana di dapat defisiensi insulin absolut atau relative dengan gangguan fungsi insulin (Perkeni, 2006).

DM telah menjadi ancaman serius bagi masyarakat. WHO memaparkan data angka kasus DM di Indonesia menempati urutan ke empat tertinggi di dunia, yaitu 8,4 juta jiwa pada tahun 2000 dan diperkirakan jumlahnya melebihi 21,3 juta jiwa pada tahun 2030 mendatang (Perkeni, 2006). Data terbaru dari Federasi Diabetes Internasional menunjukkan bahwa 285 juta jiwa yang menderita DM ternyata adalah kaum muda, yaitu antara 20-60 tahun. Data tersebut menunjukkan bahwa Indonesia termasuk dalam daftar 10 negara terbanyak menderita DM diantaranya
India, Cina, dan Amerika Serikat (SusiloWulandari, 2011).

Indonesia adalah negara yang kaya dengan bahan alam atau tanaman yang belum mengalami pengolahan apapun atau hanya diolah secara sederhana atau dikeringkan. Tanaman ini biasanya disebut dengan nama lain yaitu obat herbal. Obat herbal merupakan obat yang berasal dari tumbuh-tumbuhan dan sejak dahulu digunakan oleh masyarakat secara turuntemurun sebagai obat tradisional untuk menyembuhkan penyakit. Tanaman ciplukan memiliki efek farmakologi untuk menurunkan kadar gula dalam darah dan diuretik atau peluruh kencing dan mengobati DM (Djauhari, 2009). Tanamantanaman yang sering digunakan adalah umbi bidara upas, umbi bawang bombai, umbi bawang putih, kentang, batang brotowali, daun bungur, daun sendok, daun mengkudu, daun mimba, daun murbei, daun salam, rimpang paku simpai, paria gunung, pare, jombang, ginseng, kulit kayu manis, lenglengan, lidah buaya, sambilo, bunga tunjung, biji lamtoro, biji mahoni, biji buncis, biji rambutan, buah alpukat, buah waluh, jambu biji, beras merah dan ciplukan (Physalis angulata L) 
memiliki efek farmakologi sebagai penurun demam, penghilang nyeri, antitoksik, peredah batuk rejan, radang gusi, gondongan, hipertensi, disentri, imfluensa, bronkitis, herpes zoster, buah zakar bengkak dan antidiabetes. Ciplukan termasuk ke dalam famili tumbuhan Solanaceae dan dikenal dengan nama daerah keceplokan, nyanyoran, atau cecenet. Ciplukan memiliki berbagai kandungan kimia yang sudah diketahui antara lain seperti chorogenik acid, asam sitrun, fisalin, flavonoid, saponin dan polifeno (Dalimartha-Andrian, 2012).

Penelitian yang berkaitan tentang herba ciplukan telah dilakukan antara lain yaitu efek antidiabetes dan identifikasi senyawa dominan dalam fraksi kloroform herba ciplukan (Physalis angulata L.), efek antidiabetes herba ciplukan (Physalis angulata L.) pada mencit diabetes dengan induksi aloksan.

Hasil penelitian yang berkaitan dengan herba ciplukan (Physalis angulata L.) dengan berbagai variasi dosis pada DM terutama perubahan berat badan belum pernah dilakukan. Oleh karena itu penelitian ini dilaksanakan untuk mengetahui efek pemberian herba ciplukan terhadap perubahan berat badan yang dilakukan pada hewan coba.

\section{METODE PENELITIAN}

\section{Rancangan Penelitian}

Penelitian ini adalah
$\begin{aligned} & \text { penelitian eksperimental (true } \\ & \text { experiment designs) dengan }\end{aligned}$
rancangan pre test-post test design,
menggunakan kelompok kontrol dan
kelompok perlakuan, dengan
rancangan sederhana. Dalam
penelitian ini menggunakan tikus
Sprague dawley jantan dengan umur 3
bulan. Berat tikus yang digunakan
180-220 gr. Jumlah tikus yang
digunakan sebanyak 36 ekor dibagi
dalam 2 kelompok, yaitu kelompok
kontrol dan kelompok perlakuan.

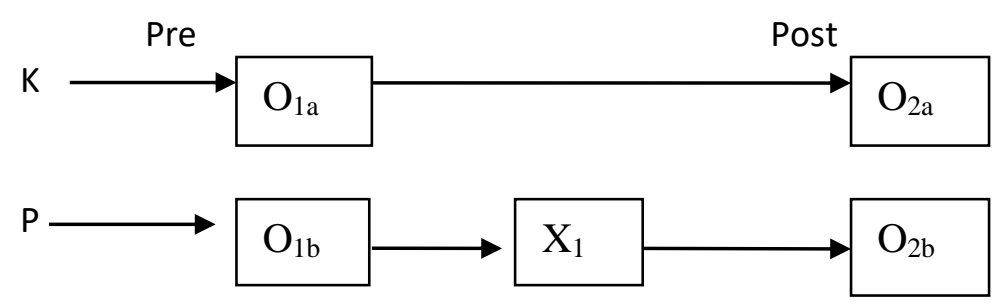

Gambar 1. Rancangan Penelitian 


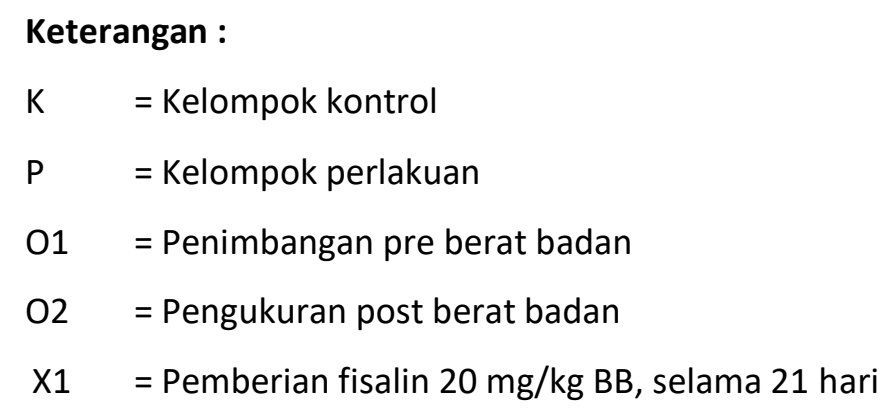

\section{Tempat dan Waktu Penelitian}

Penelitian ini berlangsung selama 1

(satu) bulan. Penyediaan hewan, pakan dan pemeliharaan hewan coba dilakukan di LPPT UGM, sedangkan pemberian ekstrak herbal ciplukan terstandar fisalin dan pemantauan berat badan di bagian FK UGM.

\section{Populasi dan Sampel}

a. Populasi dan Sampel Penelitian

Sampel penelitian merupakan hewan percobaan 36 ekor tikus jantan Sprague dawley berumur 3 bulan, berat 180-220 gr berasal dari LIPI Bogor. Tikus galur Sprague dawley dipilih karena mudah dibuat DM, pengkondisian DM dengan jalan diinduksi dengan streptozotocin. Streptozotocin (STZ) sangat cepat diserap oleh tubuh, sekitar $80 \%$ sudah ditemukan di urine dalam jangka waktu 6 jam (Oberley, 1988). Tikus galur ini juga lebih tahan lama terhadap perlakuan serta memiliki karakteristik fisiologi mirip manusia (James, 1984).

b. Besar Sampel

Sampel yang digunakan ditentukan berdasarkan rumus Federrer (Baiki dan Sudrajat, 1997), sebagai berikut: $(\mathrm{n}-1)(\mathrm{t}-1) \geq 15$

(n-1) $(2-1) \geq 15$

$N \geq 16$

Keterangan :

$\mathrm{n}=$ besar sampel

$\mathrm{t}=$ besar kelompok sampel

Dari perhitungan tersebut didapatkan jumlah sampel untuk masing-masing kelompok adalah 16 ekor tikus, dengan tambahan 2 ekor tikus untuk masing-masing kelompok. Sehingga total sampel adalah 36 ekor.

\section{Variabel dan Definisi Operasional}

a. Variabel penelitian

1. Variabel bebas dalam penelitian ini adalah dosis fisalin dari ekstrak herbal ciplukan (Physalis angulata L.).

2. Variabel terikatnya adalah perubahan berat badan tikus Sprague dawley yang diinduksi nicotinamide dan streptozotocin.

\section{Definisi Operasional Variabel}

a. Pemberian fisalin adalah pemberian hasil ekstrak herbal ciplukan (Physalis angulata L.) terstandar, yang didapat dengan 
menggunakan teknik densitometri.

Pemberiannya adalah dosis $20 \mathrm{mg} / \mathrm{kg}$ BB.

Skala : rasio

Parameter konsentrasi : mg

b. Perubahan berat badan

$\begin{array}{ll}\text { Skala } & \text { : rasio } \\ \text { Parameter } & \text { : gr } / \mathrm{kg} \mathrm{BB}\end{array}$

\section{Jenis dan Cara Pengumpulan Data}

a. Jenis data

Data yang diambil dalam penelitian ini adalah data primer. Data primer adalah data yang diperoleh langsung oleh peneliti yang merupakan hasil pengukuran. Adapun data primer yang meliputi berat pakan, sisa pakan dan perubahan berat badan selama peerlakuan.

b. Cara pengumpulan data

Dilakukan penimbangan pakan, sisa pakan dan berat badan selama perlakuan dan pemantauan perubahan berat badan berupa penimbangan berat badan dilakukan setiap hari pada saat :

1) Setelah adaptasi 7 hari tikus diinduksi nicotinamide dan streptozotocin, dilakukan penimbangan berat badan sebelum tikus diberi perlakuan pemberian fisalin.

2) Setelah perlakuan selama 21 hari dilakukan penimbangan berat badan akhir untuk mengtahui perubahan berat badan hewan coba.

c. Alat dan Bahan Penelitian

1) Alat Penelitian a) Kandang tikus individual beserta perlengkapanya.

b) Timbangan hewan coba (OHAUS)

C) Suntikan sonde

d) Timbangan analitik

2) Bahan penelitian

a) Tikus jantan galur Sprague dawley, dengan berat $180-200 \mathrm{gr}$

b) Pakan AIN 93 dan aguadest

c) Ekstrak herbal ciplukan terstandar fisalin (Physalis angulata L.)

\section{Jalannya Penelitian}

a. Tahap Persiapan

1) Mengurus atministrasi laboratorium dan perizinan penggunaan laboratoriun.

2) Penyediaan hewan coba yaitu tikus putih galur Sprague dawley jantan dengan berat 180-220 gr, dan berumur 3 bulan dengan jumlah 20 ekor.

3) Penyediaan fisalin terstandar dari ekstrak herba ciplukan (Physalis angulata L.) $20 \mathrm{mg}$, dengan teknik densitometri.

4) Penyediaan pakan AIN 93 dan aquadest

5) Penyediaan alat-alat penelitian yaitu kandang tikus individual, timbangan hewan coba (OHAUS) dan suntikan sonde. 
Pengukuran berat badan

dilakukan setiap hari

Suntikan STZ + Nicotinamide

Hari ke 8 dan penimbangan berat badan awal

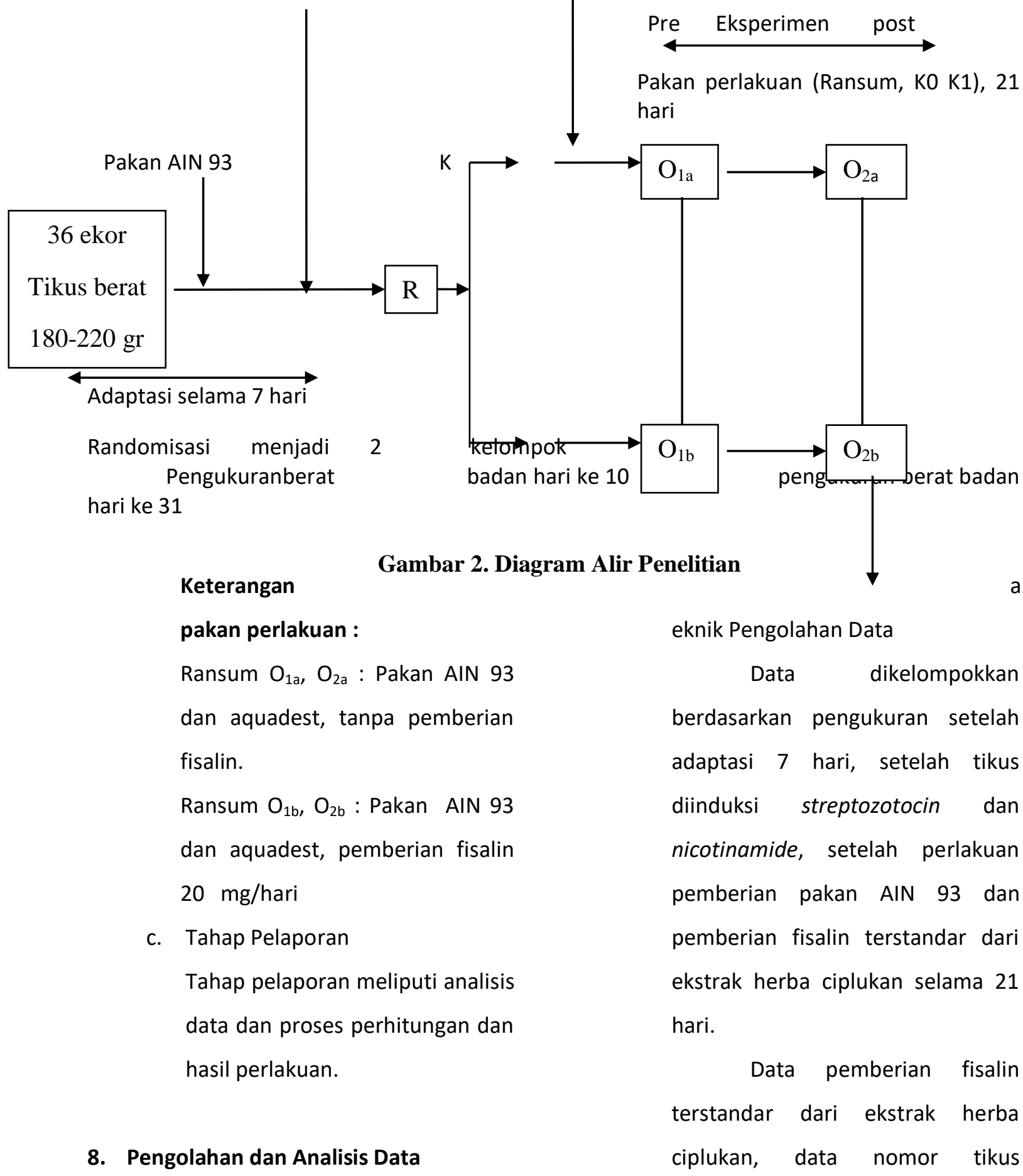




dikelompokkan dengan berat
badan dan sisa pakan, nomor
kelompok dan tanggal
penimbangan. Data yang ada
dikumpulkan dalam satu tabel
kemudinan dianalisis dan dilihat
perbedaannya antara tiap
perlakuan berdasarkan waktu
penimbangan.

b. Analisis Data

Pada akhir penelitian dilakukan analisis data secara kuantitatif meliputi analisis statistik deskriptif. Analisis deskriptif disajikan dalam bentuk tabel dan gambar. Uji beda dalam kelompok perlakuan dengan independen $T$ Test. Fasilitas penyajian data menggunakan komputer.

\section{HASIL DAN PEMBAHASAN}

\section{a. Hasil}

1. Berat Badan Tikus Sprague dawley Selama Penelitian

Berat badan tikus diikuti selama untuk mengetahui berat badan selama 4 minggu perlakuan. Setiap minggu tikus dilakukan penimbangan berat badan untuk mengetahui perubahan berat badannya selama penelitian. Penimbangan berat badan yang dilakukan pada minggu ke 0 pada adaptasi hari ke-5 untuk mengetahui berat badan awal sebelum di induksi Streptozotocin minggu pertama sebelum di lakukan penelitian sudah dilakukan pengukuran berat badan untuk mengetahui berat badan tikus sebelum di induksi Streptozotocin dan diberi ekstrak herba ciplukan (Physalis angulata L) terstandar fisalin didapatkan berat badan tikus awal dan dilanjutkan dengan penimbangan berat badan untuk mengetahui berat badan setelah sebelum perlakuan dan setelah perlakuan. Rerata berat badan selama penelitian dapat dilihat gambar 3.

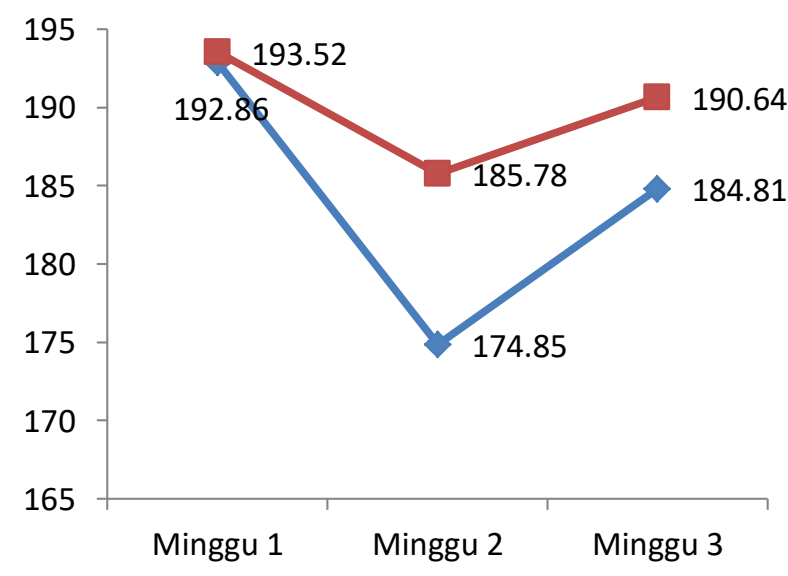

Gambar 3. Grafik Berat Badan Tikus Selama Penelitian

Berdasarkan tabel di atas dapat di lihat bahwa perubahan berat 
badan awal yang mengalami mengalami peningkatan berat badan. Berat badan tikus selama penelitian mengalami peningkatan dan penurunan pada kelompok kontrol dan kelompok perlakuan, di minggu ke 2 terjadi penurunan namun di minggu ke 3 berat badannya naik lagi, kemudian di minggu ke 4 terjadi peningkatan berat badan seperti yang tersaji pada gambar 4 .

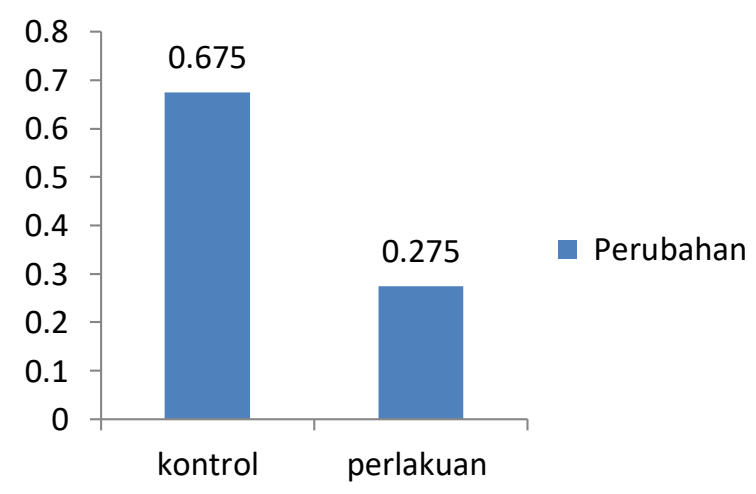

Gambar 4. Grafik Perubahan Berat

Badan Tikus Selama Penelitian

Berdasarkan gambar diatas dapat

diketahui bahwa berat badan tikus

Pre berdasarkan hasil

penimbangan berat badan pada

minggu ke 2 sebelum di induksi

Streptozotocin medapatkan hasil

penimbangan dengan rata-rata

pada kelompok kontrol sebesar

174,85 gr dan kelompok perlakuan sebesar 185,78 gr sedangkan pada berat badan tikus Post atau setelah di induksi Streptozotocin pada minggu ke-3 mendapatkan hasil penimbangan dengan rata-rata untuk kelompok kontrol sebesar 187,62 gr dan kelompok perlakuan sebesar 193,27 gr. Dari hasil berat badan diatas dilakukan uji independent T-tes yang menunjukan bahwa perbedaan berat badan antara kelompok control, dan kelompok perlakuan pada kelompok kontrol 0,675 gr dan pada kelompok perlakuan memiliki rata-rata berat badan 0,275 gr.

\section{Asupan Makan Selama Perlakuan} pada Tikus Sprague Dawley

Tinjauan dari asupan makan dari sisa pakan pada penelitian ini diberikan pakan AIN 93 sebanyak \pm 15 gr setiap hari. Selama perlakuan sisa pakan ditimbang untuk dimonitoring asupan pakan tikus dan untuk melihat apakah ada efek antara kelompok kontrol yang tidak diberi ekstrak herba ciplukan (Physalis angulata L) terstandar fisalin dan kelompok perlakuan yang diberi ekstrak herba ciplukan 
terstandar fisalin. Perubahan sisa

pakan tikus selama perlakuan dapat dilihat pada gambar 5 .

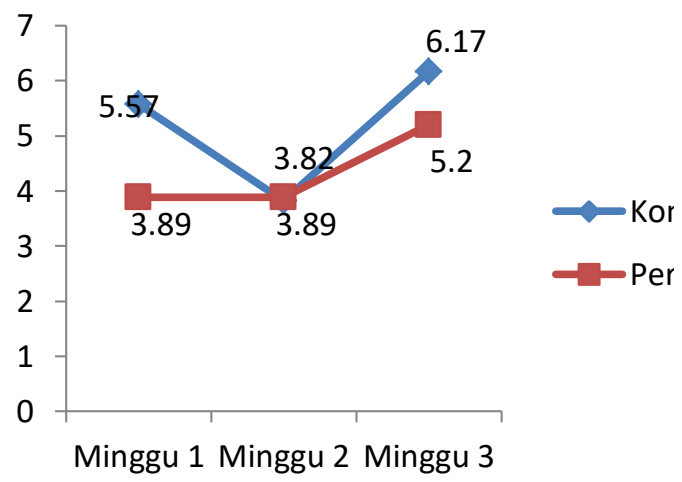

Gambar 5. Grafik Perubahan

Asupan Makan Pada Tikus Selama

Perlakuan

Sisa pakan antara kelompok kontrol dengan kelompok perlakuan terlihat ada sedikit perbedaan. Pada kelompok kontrol apabila dilihat dari sisa pakan maka asupan pakan tikus pada minggu ke 1 sampai minggu ke 2 tidak mengalami peningkatan maupun penurunan namun pada minggu ke 3 asupan pakannya mengalami penurunan.

Hal ini menunjukkan bahwa asupan pakan tidak dipengaruhi oleh pemberian ekstrak herba ciplukan (Physalis angulata L) terstandar fisalin dengan kata lain, tidak ada efek pemberian ekstrak herba ciplukan (physalis angulata L) terstandar fisalin terhadap nafsu makan tikus.

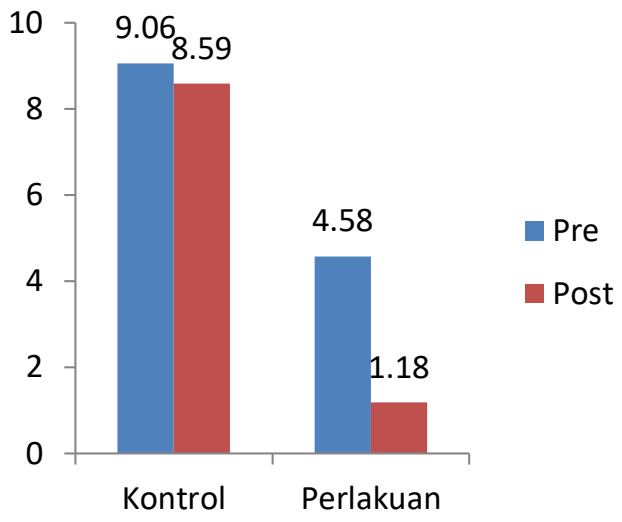

Gambar 6. Grafik Perubahan Asupan Makan Pada Tikus Pre dan Post Berdasarkan gambar 6 menunjukkan asupan makan tikus yang dilihat dari sisa pakan bahwa antara kelompok kontrol dan perlakuan yang dilihat dari sebelum perlakuan dan setelah perlakuan sisa pakan tikus sebelum perlakuan (pre) lebih meningkat dibandingkan dengan kelompok perlakuan (post). Dari pengamatan yang dilakukan antara kelompok pre dan post yang dilihat dari kelompok tikus yang dilakukan pemberian ekstrak herbal ciplukan terstandar fisalin berpengaruh terhadap konsumsi pakan pada kelompok tikus setelah 
perlakuan. Dari perhitungan sisa pakan menggunakan perubahan $(\Delta)$ mendapatkan rata-rata sisa pakan pre $0,52 \mathrm{gr}$ dan sisa pakan post $0,23 \mathrm{gr}$.

\section{Poliuria}

Pada pengamatan yang ada yang dilihat dari pengamatan dari minggu ke -1 sampai pada minggu ke -3 terdapat perbedaan antara hewan coba yang di induksi dan yang yang tidak di induksi. Dari rata-rata yang ada tikus yang mengalami poliuria pada minggu ke-1 pada kelompok kontrol mengalami poliuria dengan ratarata 83 tikus, sedangkan kelompok perlakuan 102 tikus. Pada minggu ke-2 kelompok kontrol jumlah tikus yang banyak mengalami poliuria dengan rata-rata 106 tikus sedangkan kelompok perlakuan tidak mengalami penurunan sebayak 110 tikus. Sedangkan pada minggu ke-3 mengalami penurunan karena jumlah tikus yang mengalami poliuria dengan ratarata pada kelompok kontrol 53 tikus dan kelompok perlakuan 63 tikus. Hal ini menunjukkan bahwa pemberian ekstrak herbal ciplukan tidak memberikan efek atau khasiat untuk memperbaiki organ tubuh pada tikus untuk mencegah terjadinya polyuria. Hal ini dapat dilihat pada grafik pada gambar 7 .

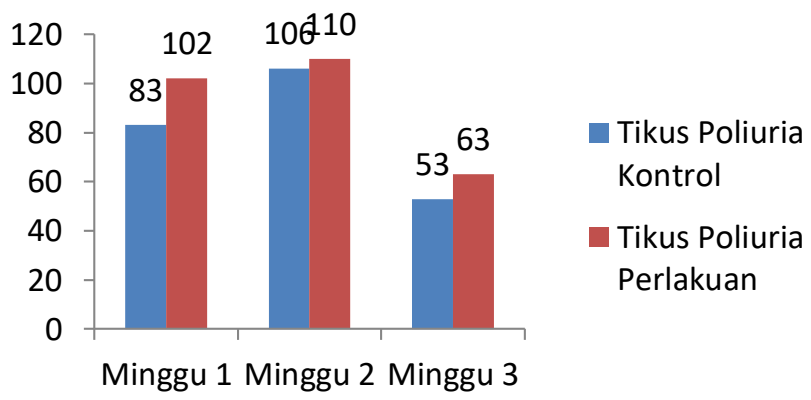

Gambar 7. Grafik Perubahan Tikus yang Mengalami Poliuria

Berdasarkan gambar 7 menunjukkan bahwa kelompok tikus kontrol lebih sedikit mengalami poliuria di bandingkan kelompok tikus perlakuan. Pada grafik tersebut pada pengamatan poliuria pada minggu ke 1 dan ke 2 tikus yang paling banyak mengalami poliuria adalah kelompok tikus perlakuan dan pada minggu sedangkan pada minggu ke 3 ada perubahan yaitu tikus yang mengalami poliuria mulai berkurang tetapi yang paling bayak mengalami poliuria adalah tikus pada kelompok perlakuan.

\section{b. Pembahasan}

Diabetes melitus (DM) adalah penyakit gangguan metabolisme yang ditandai dengan hiperglikemia yang disebabkan karena kekurangan hormon 
insulin atau penurunan aktivitas biologi hormon insulin atau keduanya. Seperti kita ketahui perubahan berat badan pada penderita Diabetes Mellitus merupakan gejala awal yang terjadi penurunan berat badan karena glukosa darah tidak dapat masuk ke dalam sel sehingga tidak mempunyai bahan bakar untuk menghasilkan tenaga dan menggunakan cadangan lemak dan otot penderita sehingga penderita mengalami penurunan berat badan (Karyadi, 2002).

Perubahan berat badan yang terjadi setelah di induksi pada minggu ke 2 terjadi penurunan berat badan apabila dibandingkan pada minggu ke 1 baik pada kelompok kontrol maupun kelompok perlakuan. Hal ini disebabkan karena tikus menderita diabetes mellitus akibat di induksi Streptozotocin. Streptozotocin adalah senyawa campuran glukosaminnitrosourea. Nama kimia senyawa ini adalah 2-deoksi-2-(3-metil-3nitrosoureido-D-glokopiranosa

$\left(\mathrm{C}_{6} \mathrm{H}_{15} \mathrm{~N}_{3} \mathrm{O}_{7}\right)$. Senyawa ini dapat masuk ke dalam sel melalui transporter glukosa (GLUT 2). Sel $\beta$ pankreas memiliki jumlah GLUT 2 lebih banyak daripada sel-sel tubuh lainnya sehingga streptozotocin memiliki toksisitas selektif terhadap sel $\beta$ pankreas (Ling Li, 2001).

Fungsi pankreas adalah memproduksi insulin untuk memproses asupan glukosa sebagai sumber energi. Pada orang yang menderita diabetes, tubuhnya gagal mengelola gula menjadi energi sehingga terjadinya resistensi insulin. Akibatnya tubuh mengolah zat-zat lain dalam tubuh untuk diubah menjadi energi sehingga berat badan turun. Penurunan berat badan disebabkan karena terjadinya poliuria, polidipsi, sekalipun asupan kalorinya terus memadai, hal ini merupakan gejala utama defisiensi insulin. Dari pengamatan yang dilkukan selama penelitian tikus mengalami semua gejala defisiensi insulin sehingga menyebabkan penurunan berat badan.

Ditinjau dari data berat badan tikus Diabetes Melitus selama penelitian berlangsung pada minggu ke-1 mengalami peningkatan berat badan dan setelah minggu ke-2 mengalami penurunan berat badan tetapi setelah minggu ke-3 tikus mengalami penambahan berat badan. Peningkatan berat badan pada tikus pada minggu ke-1 dikarenakan hewan percobaan belum mengalami gejala penurunan berat badan yang diakibatkan oleh gangguan penyakit 
DM. sedangkan pada minggu ke-2 tikus mengalami penurunan berat badan hal ini disebabkan karena tikus mengalami gejala DM setelah di induksi Nicotinamide dan Ztreptozotocin. Perubahan berat badan yang terjadi merupakan salah satu gejala pada penderita DM yaitu terjadi penurunan berat badan karena glukosa dalam darah tidak masuk ke dalam sel sehingga tidak mempunyai bahan bakar untuk menghasilkan tenaga sehingga menggunakanan cadangan lemak dan otot dalam tubuh, Bersamaan dengan munculnya gejala DM. Tikus DM dalam penelitian ini juga mengalami penurunan berat badan. Penurunan berat badan tersebut dikarenakan jaringan yang mengalami resistensi reseptor insulin memecah lemak untuk mendapatkan energi alternatif dan terjadi kerusakan organ tubuh seperti pankreas dan ginjal sehingga terjadi penurunan berat badan (Ashaeryanto dkk, 2011).

Penambahan berat badan pada kelompok kontrol karena pemberian pakan AIN 93 dapat memulihkan organorgan tubuh pada tikus yang rusak sehingga dapat membantu meningkatkan berat badan pada kelompok kontrol walaupun peningkatan berat badan pada kelompok perlakuan lebih besar dibandingkan dengan kelompok kontrol. Sedangkan pada kelompok perlakuan yang diberikan pakan AIN 93 dengan pemberian $15 \mathrm{gr} /$ ekor tikus dan pemberian ekstrak herba ciplukan terstandar fisalin dengan dosis 20 $\mathrm{mg} / \mathrm{kg}$ BB mengalami penigkatan berat badan hal ini disebabkan karena pemberian ekstrak herba ciplukan terstandar fisalin yang mengandung efek farmakologi untuk menurunkan kadar gula darah dan membantu dalam penyerapan zat gizi pada diet yang diberikan sehingga memperbaiki organorgan dalam tubuh yang rusak sehingga meningkatkan berat badan tikus. Hal ini sependapat dengan penelitian Sianturi, dkk (2013) yang menyatakan pemberian ekstrak herba ciplukan (Physalis angulata $\mathrm{L}$ ) terstandar fisalin mampu menurunkan kadar gula darah pada tikus diabetes dan sejalan dengan penelitian Laila, dkk (2013) yang menyatakan bahwa pemberian ekstrak herba ciplukan (Physalis angulata L) mampu meningkatkan berat badan tikus diabetes. Hal ini bertujuan untuk mempertahankan berat badan dan mencegah terjadinya penurunan berat badan akibat terjadinya gejala pada DM. 


\begin{abstract}
Pemberian ekstrak herba ciplukan (Physalis angulata L) terstandar fisalin juga mempengaruhi metabolisme lemak yaitu mampu menurunkan kadar trigliserida dan menaikkan kadar HDL sehingga akan mencegah terjadinya proses lipolisis. Hal ini disebabkan karena fisalin merupakan golongan steroid yang mampu meningkatkan deferensiat lemak. Sependapat dengan penelitian Rahayu, dkk yang mengungkapkan bahwa pemberian ekstrak herba ciplukan (Physalis angulata L) terstandar fisalin mampu menurunkan kadar trigliserida dan menaikan kadar HDL pada tikus diabetes.

Setelah dilakukan uji statistik berdasarkan perubahan $(\Delta)$ didapatkan hasil yaitu rata-rata berat badan pada kelompok kontrol 0,675 gr dan pada kelompok perlakuan memiliki rata-rata berat badan 0,275 gr. Untuk mendapatkan hasil perbedaan berat badan antara kelompok kontrol dan perlakuan dilakuan uji Independen Ttest mendapatkan hasilnya adalah sama yaitu tidak terdapat perbedaan yang signifikan pada setiap kelompok. Hal ini dapat dilihat pada hasil uji statistik yang mendapatkan nilai yang tidak signifikan $p=0,47$.
\end{abstract}

Perubahan berat badan dapat dilihat pada hasil perhitungan menggunakan perubahan $(\Delta)$ sisa pakan selama penelitian berlangsung pada perlakuan pre dan post. Sisa pakan pada kelompok pre mendapatkan hasil sisa pakan menggunakan perubahan $(\Delta)$ mendapatkan rata-rata sisa pakan pre $0,52 \mathrm{gr}$ dan sisa pakan post $-0,23 \mathrm{gr}$ dan hasil uji Independent T-test menunjukkan hasil yang signifikan yaitu $p=0,002$.

Pada pengamatan hewan coba menujukkan bahwa penambahan berat badan yang terjadi pada kelompok tikus kontrol yang mengalami DM mengalami penurunan asupan sehingga terjadi peningkatan sisa pakan. Penambahan berat badan yang terjadi pada kelompok kontrol disebabkan karena kelompok tikus perlakuan di lihat dari hasil pengamatan jumlah tikus yang mengalami poliuria dibandingkan keldengan jumlah sedikit kompok perlakuan. Hal ini yang menyebabkan adanya penambahan berat badan pada tikus kontrol karena terjadi penumpukan cairan pada perut tikus atau mengalami acites. Asites adalah menumpuknya cairan patoligis dalam rongga abdominal atau perut. 
Penumpukan cairan asites menggambarkan kadar natrium total dalam tubuh dan pengeluaran air.

Pada kelompok perlakuan lebih banyak mengalami poliuria dibandingkan pada kelompok kontrol. Hal ini disebabkan karena adanya penurunan fungsi ginjal akibat diabetes mellitus dimana fungsi ginjal mengalami penurunan yang progresif secara perlahan tapi pasti dari kondisi normal menuju ketidakmampuan ginjal ditandai tubuh gagal untuk mempertahankan metabolisme dan keseimbangan cairan dan elektrolit. Hal ini tidak sejalan dengan penelitian Anggiana, dkk (2013) menyatakan pemberian ekstrak herba ciplukan (Physalis angulata L) mampu memperbaiki fungsi ginjal pada tikus diabetes.

\section{SIMPULAN}

Berdasarkan hasil penelitian Pengaruh Pemberian Ekstrak Herbal Ciplukan (Physalin angulata L) Terstandar Fisalin Terhadap Perubahan Berat Badan Tikus (Sprague dawley) yang di Induksi Nicotinamide dan Streptozotocin dapat disimpulkan bahwa :

a. Berat badan awal tikus (Sprague dawley) sebelum di induksi Nicotinamide dan Streptozotocin dengan rata-rata berat badan kontrol 174,85 gr dan perlakuan $185,78 \mathrm{gr}$.

b. Berat badan tikus setelah di induksi Nicotinamide dan Streptozotocin mengalami penurunan berat badan pada kelompok kontrol dengan ratarata $184,81 \mathrm{gr}$ dan kelompok perlakuan $190,64 \mathrm{gr}$.

c. Ekstrak herba ciplukan tidak memberikan efek atau khasiat terhadap penambahan berat badan tikus (Sprague dawley) perlakuan dengan pemberian dosis $20 \mathrm{ml} / \mathrm{kg}$ BB dengan Perubahan $(\Delta)$ rata-rata berat badan pada kelompok kontol 0,675 gr dan kelompok perlakuan 0,275 gr.

\section{DAFTAR PUSTAKA}

Perkeni, 2006. Konsensus Pengelolaan dan Pencegahan Diabetes Melitus Tipe 2 di Indonesia. PB Perkeni.

Susilo, Y., Wulandari, A. 2011. Cara Jitu Mengatasi Diabetes Melitus (Kencing Manis), Yogyakarta: C.V Andi

Djauhari, A. 2009. 150 Resep Herbal Untuk Menaklukkan Diabetes Melitus, Yogyakarta: CV. Solisi Distribusi.

Dalimartha, S dan Adrian, F (2012). Makanan dan Herbal untuk Penderita Diabetes Melitus, Jakarta: Penebar Swadaya. 
Jurnal IImiah Respati

Karyadi, Elvina. 2002. Kiat Mengatasi

Penyakit Diabetisi, hiperkolesteromia

dan stroke. Jakarta: Intisari

Mediatama

Ling Li. 2001. Streptozotocin. Free Radicals

in Biology and Medicine, 77 (222).
Ashaeryanto, Tiara, M dan Kawijaya, D.

2001. Berat Badan Menurun. Fakultas

Kedokteran Universitas Haldoleo

Kendari. 